\title{
Preliminary Study on Remediation of Contaminated Clay Soil Using Cement and Sugarcane Bagasse
}

\author{
Mohamad Azim Mohammad Azmi ${ }^{1}$, Saiful Azhar Ahmad Tajudin ${ }^{2,}$, Shahiron Shahidan ${ }^{3}$, \\ Md Asrul Nasid Masrom ${ }^{4}$, and Ain Nabila Abdul Talib ${ }^{5}$ \\ ${ }^{1,2,5}$ Research Centre for Soft Soil (RECESS),University Tun Hussein Onn Malaysia, \\ 86400 Johor, Malaysia \\ ${ }^{1,2,3}$ Faculty of Civil and Environmental Engineering,University Tun Hussein Onn \\ Malaysia, 86400 Johor, Malaysia \\ ${ }^{4}$ Faculty of Technology, Management and Bussiness, University Tun Hussein Onn \\ Malaysia, 86400 Johor, Malaysia
}

\begin{abstract}
Disposals of agricultural waste in a large volume have an extremely harmful effect on the environment if they are ineffectively treated. To solve this, several appropriate methods has been identified to produce new recycling technique of utilizing the agricultural waste. In this study, the feasibility of using sugarcane bagasse (SCB) as partial replacement binder with cement to stabilized and solidified $(\mathrm{S} / \mathrm{S})$ the contaminated soil are investigated. This paper focused on the strength and the leaching characteristic of lead $(\mathrm{Pb})$ contaminated soil treated with SCB and cement. Two tests, namely the Unconfined Compressive Strength (UCS) test and Toxicity Characteristic Leaching Procedure (TCLP) were employed to measure the strength and leaching performance of $\mathrm{S} / \mathrm{S}$ samples. The experimental results demonstrated that the UCS at 28 days was in a range of 0.82 to $5.66 \mathrm{MPa}$ for sample containing cement and SCB compare to $0.29 \mathrm{MPa}$ of control mix at the same age. The concentration of $\mathrm{Pb}$ in the leachates was within the limits specified by US EPA as low as $2.11 \mathrm{mg} / \mathrm{L}$ in 28 days. This shows that, the quality of $\mathrm{S} / \mathrm{S}$ sample containing cement and SCB significantly improve the strength development as well as effectively in reducing the $\mathrm{Pb}$ leachability. Based on the finding, SCB could be useful as cheaper, easy available alternatives binder for the treatment of contaminated soil.
\end{abstract}

\section{Introduction}

Soil that is contaminated by heavy metals is a worldwide problem that requires urgent attention. Heavy metals in soil may cause threat to human health either through accidental soil ingestion, breathing in contaminated soil dust particles or by ingesting polluted drinking water or farm products tainted by contaminated soil [1]. On the other hand, heavy metal contaminated soil is mainly due to the subsequent migration of leachate form and

*Corresponding author: saifulaz@uthm.edu.my 
within the landfill waste cell. According to fauziah et al. [2], the natural process taking place within the boundaries of the waste cells accelerate the process of heavy metal leaching from the waste components sources of heavy metal within a landfill system. The released of heavy metal into the adjacent environment is a serious environmental concern and a threat to public health and safety [3].

Kamari et al., [4] claimed that heavy metal behavior in soil and biological effects are caused by their presence in increased concentrations. Heavy metal behavior is in fact largely determined by the processes of metal released from the solid phase into the soil solution and factors influencing the chemical forms of metal in soil. The contamination of soil by heavy metal, particularly lead $(\mathrm{Pb})$, is a common problem throughout the world [5]. Lead has been reported as a metal that affect the human nervous system, blood vessels and kidneys. Currently, the governments are trying to minimize the lead impact that produce adverse effects on the mental and physical development of humans, even at the lower exposure level [6]. Therefore, remediation of contaminated soil is of great importance for both engineers and researchers. The stabilization/Solidification $(\mathrm{S} / \mathrm{S})$ remediation method has been employed as a potential technology with the addition of a binding agent to reduce the movement of hazardous waste elements due to its low cost, availability and versatility [7].

\section{Materials and methods}

\subsection{Binder system and soil contaminated process}

Clay used for this study was collected at a location near the Research Center for Soft Clay (RECESS), University Tun Hussein Onn Malaysia (UTHM). The soil sample was dried in an oven at $105^{\circ} \mathrm{C}$ for 24 hours at the laboratory. After undergoing a drying process for 24 hours, the soil was crushed using a rubber hammer before it was reduced to $2 \mathrm{~mm}$ in size by a grinder machine. The soil particles which pass the $2 \mathrm{~mm}$ sieve were stored in polyethylene plastic. The initial concentration of $\mathrm{Pb}$ would be $500 \mathrm{ppm}$. The selection of this percentage would be to test the worst case of the contaminated soil. Type II ordinary Portland cement (OPC) was used as the main binder together with treated sugarcane bagasse (SCB) in order to treat the lead contaminated soil. The SCB was collected from sugarcane juice hawker located around Parit Raja, Johor with the SCB underwent a treatment process under acidic conditions to remove cellulose fibers and to liberate the lignin. The SCB was boiled with $0.1 \mathrm{M} \mathrm{HCl}$ for 45 minutes and the residue was washed to rid it of sugars and hydrolysis products. This procedure was repeated 3 to 4 times until the filtrate became colorless. Finally, the SCB was dried in the oven at a temperature of $105^{\circ} \mathrm{C}$ for 24 hours to remove all moisture content before being grinded into particles measuring $90 \mu \mathrm{m}$ in size.

The raw materials were mixed by using a small mixer to ensure the homogenous of the $\mathrm{S} / \mathrm{S}$ sample. Then, $\mathrm{S} / \mathrm{S}$ sample then compacted in a split mould to form a sample of $38 \mathrm{~mm}$ in diameter and $76 \mathrm{~mm}$ in height. A specially designed miniature hand compacting tool was used to compact the mixture in 4 layers, 50 blows each. The extruded specimens were then wrapped and stored for 7, 14 and 28 days. Table 1 shows the mix design of S/S sample used in this study. 
Table 1. Sample mix proportions (by weight)

\begin{tabular}{|c|c|c|c|c|c|}
\hline \multicolumn{3}{|c|}{ Binder } & \multirow{2}{*}{$\begin{array}{c}\text { Total weight } \\
\text { of the } \\
\text { sample (g) }\end{array}$} & \multirow[b]{2}{*}{$\mathbf{w} / \mathbf{b}$} & \multirow[b]{2}{*}{ Symbol } \\
\hline Clay soil (\%) & OPC (\%) & $\begin{array}{r}\text { SCB } \\
(\%)\end{array}$ & & & \\
\hline 95 & 5 & - & 160 & 0.4 & C95O5 \\
\hline 95 & 2.5 & 2.5 & 160 & 0.4 & C95O2.5S2.5 \\
\hline 90 & 10 & - & 160 & 0.4 & $\mathrm{C} 90010$ \\
\hline 90 & 5 & 5 & 160 & 0.4 & C90O5S5 \\
\hline 85 & 15 & - & 160 & 0.4 & $\mathrm{C} 85 \mathrm{O} 15$ \\
\hline 85 & 7.5 & 7.5 & 160 & 0.4 & C85O7.5S7.5 \\
\hline 100 & - & - & 160 & 0.4 & control \\
\hline
\end{tabular}

\subsection{Unconfined compressive strength (UCS)}

The UCS test has been carried out by using the Geocomp LoadTrac II system available in RECESS UTHM. Testing was conducted according to BS1377-7:1990. The samples were extruded from the moulds, leveled, measured for length and diameter, weighed and subjected to uniaxial compression test (UCT) at a constant rate of strain of $1 \%$ per minute. Before testing, the loading device was adjusted carefully to ensure the upper platen just makes contact with the sample. Care was taken to ensure that both ends of the sample were as flat as possible to minimize bedding error during the test, especially the stiffer samples. The tested samples than collected and dried in the oven at $105 \mathrm{oC}$ for 24 hours before being crushed to pass through a $1 \mathrm{~mm}$ sieve prior to TCLP testing.

\subsection{Toxicity characteristic leaching procedure (TCLP)}

A TCLP test was conducted by adding a fixed volume of TCLP leachant No. $2(5.7 \mathrm{ml} / 1$ glacial acetic acid aqueous solution at $\mathrm{pH} 2.88)$ to 20 times the weight of the sample (20:1). The extraction period for the sample lasted 18 hours under rotary agitation at $30 \mathrm{rpm}$. The sample was then filtered using Grade GF/F $0.7-\mu \mathrm{m}$ glass fiber filter paper and the $\mathrm{pH}$ was measured at the end of the process. The sample was filtered within $2 \mathrm{~h}$ of the $18 \mathrm{-h}$ extraction period to ensure method reproducibility [8]. This procedure differs from the EPA TCLP [9] method in that one-tenth (1:10) of the amount of the sample was used. Apart from the modified step, all another aspect of the method remained the after filtration, metal concentrations in the leachate was determined via Perkin-Elmer AA800 Atomic Absorption Spectrometer (AAS).

\section{Result and discussion}

\subsection{Strength development of cement-SCB}

Compressive strength is an important factor as it determines the load that can be carried by a material. The strength of the mixture depends on the additive added. The results of the strength of $\mathrm{S} / \mathrm{S}$ are presented in Fig. 1. It could be seen that sample with $100 \%$ OPC (sample C95O5, C90O10 and C85015) has a highest compressive strength that is 0.73 Mpa, 2.79 Mpa and 5.66 Mpa respectively at 28 curing days. While, control sample shows the lowers strength with only $0.29 \mathrm{Mpa}$ at 28 days. Sample with treated SCB performs an intermediate compressive strength ranging from $0.35 \mathrm{Mpa}$ to $1.39 \mathrm{Mpa}$. When SCB added 
as a partial replacement in OPC, the strength becomes weaker compared to the sample without SCB. This is contributed by cement percentage ranging $5 \%$ to $20 \%$ are routinely used to stabilized and solidified contaminated soil. Low cement content causes the individual soil particles to be inadequately coated. However, it has a tendency to form a rigid form of waste [10].

Additionally, the figure also presents the UCS of S/S lead spike soil sample at 7, 14 and 28 days. It is obviously shown that a sample containing 100\% OPC has the highest strength than another sample. This evidently shows the effect of using OPC as additive in the contaminated sample. It can be concluded that hydration time also effect the strength development. All samples become more harden for 28 days [11-14]. This is caused by the slow formation of calcium hydrated silicates (C-S-H) which resulted from the reaction of anhydrous-silicate constituents of cement with water [15][16]. However, even the UCS of sample with SCB are not high compared to sample without SCB, the result is still exceeded the minimum landfill disposal limit stated by US EPA of $0.35 \mathrm{Mpa}(350 \mathrm{kPa})$ at 28 curing days.

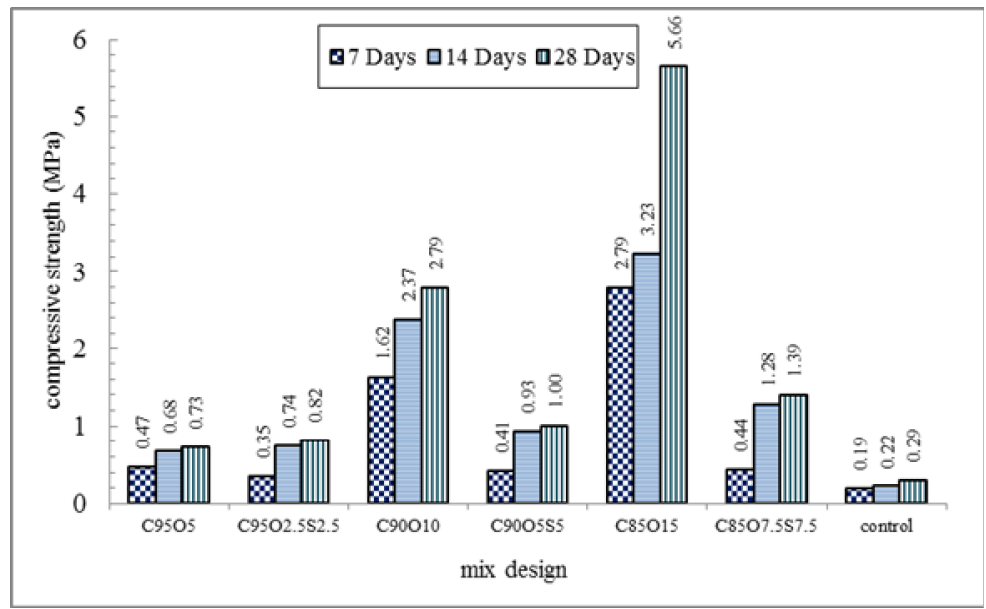

Fig 1. Strength development of S/S sample

\subsection{Leachability of the $\mathrm{Pb}$}

In this study, Toxicity Characteristic Leaching Procedure TCLP test has been conducted to investigate the leaching characteristic that is suitable for organic waste or waste containing high sulfate compounds. This testing produced leachate that is similar to the leachate obtained from a sanitary landfill site and found to deplete various types of metal [17]. The Fig. 2 shows the $\mathrm{Pb}$ leachability at 7,14 and 28 days. The figures demonstrate that the concentration of $\mathrm{Pb}$ in $\mathrm{S} / \mathrm{S}$ sample depends on two main factors which are mix ratio and curing days. The higher reduction is showed by sample C8507.7S7.5 with $\mathrm{Pb}$ concentration $6.23 \mathrm{mg} / \mathrm{L}, 4.26 \mathrm{mg} / \mathrm{L}$ and $2.11 \mathrm{mg} / \mathrm{L}$ at 7,14 and 28 days respectively. The small reduction are showed by control sample with $236.11 \mathrm{mg} / \mathrm{L}, 183.19 \mathrm{mg} / \mathrm{L}$ and $93 \mathrm{mg} / \mathrm{L}$ at 7,14 and 28 days respectively. This scenario is expected because the leachability of heavy metals in $\mathrm{S} / \mathrm{S}$ method depends on the hydration days. It is proved by Antemir et al. [18] which stated that the long-time hydration of S/S sample has been decreased the leachability in groundwater. This is also supported by Wang et al. [19] which study the leachability of heavy metals at 17 years old $\mathrm{S} / \mathrm{S}$ site and found that, the slow bonding reaction happen between metals and binder. 
Apart from that, the figure also indicates that sample containing SCB has leached out least amount of $\mathrm{Pb}$ in final leachate. In a nutshell, the research has found that $\mathrm{SCB}$ as a fibre material, when incorporated with $\mathrm{OPC}$ has been successful adsorbed the $\mathrm{Pb}$ in $\mathrm{S} / \mathrm{S}$ method.

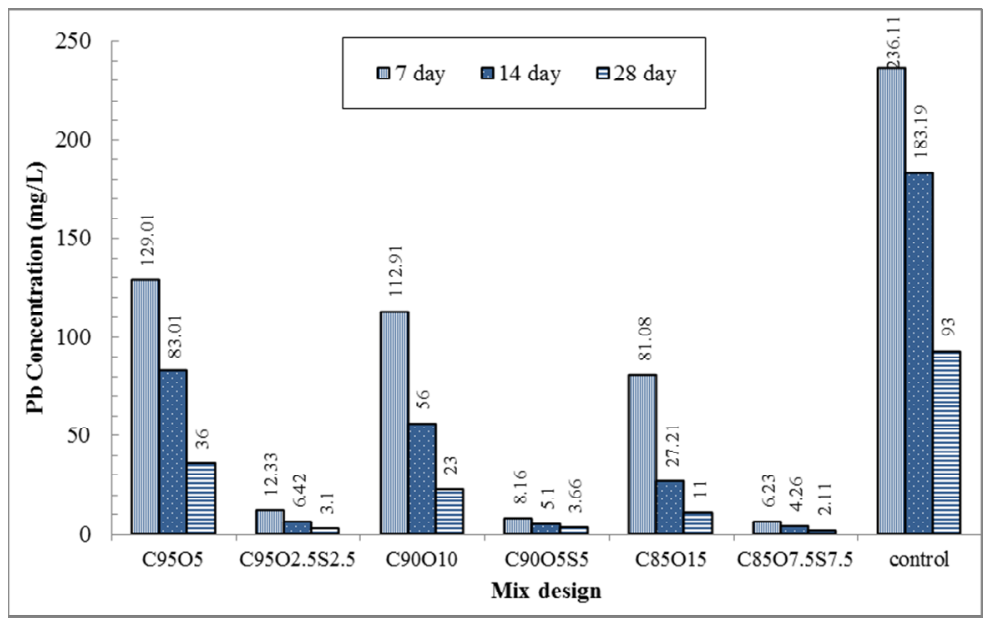

Fig 2. Leachability of S/S sample

\section{Conclusion}

From the study, it was found that the use of SCB is not substantial enough for obtaining the highest strength compared to a sample containing only OPC. However, all samples exceeded the landfill disposal limit of $0.34 \mathrm{Nmm}^{2}$ or $340 \mathrm{kPa}$. The UCS at 28 days was in a range of 0.82 to $5.66 \mathrm{MPa}$ for sample containing cement and SCB compare to $0.29 \mathrm{MPa}$ of control mix at the same age. Despite that, the TCLP extraction has been successful in reducing the concentrate of $\mathrm{Pb}$ below the standard limit set by US EPA. The concentration of $\mathrm{Pb}$ in soil samples containing $\mathrm{OPC}$ and $\mathrm{SCB}$ remain low. For example, a sample containing $15 \%$ OPC leached out the $\mathrm{Pb}$ at $11 \mathrm{mg} / \mathrm{L}$ at 28 days of curing. The better result showed by a sample containing $7.5 \%$ OPC $+7.5 \%$ SCB that is $2.11 \mathrm{mg} / \mathrm{L}$. This significant reduction indicates that the use of $\mathrm{SCB}$ as a partial replacement is possible to reduce the concentration of $\mathrm{Pb}$ in the final leachate. In the same way, all sample containing SCB as additive materials to OPC obtained the US EPA limit $(<5 \mathrm{mg} / \mathrm{L})$.

The authors would like to thank the Ministry of Higher Education and Universiti Tun Hussein Onn, Malaysia for supporting this research under the Exploratory Research Grant Scheme (ERGS) Vot. 40.

\section{References}

[1] P. Yin and L. Shi, Remediation of $\mathrm{Cd}, \mathrm{Pb}$, and $\mathrm{Cu}$-Contaminated Agricultural Soil Using Three Modified Industrial By-products, Water, Air, Soil Pollu, An Inter.J. Enviton.Poll., 225 11,2194 (2014)

[2] S. H. Fauziah, M. N. Izzati, and P. Agamuthu, Toxicity on Anabas Testudineus: A Case Study of Sanitary Landfill Leachate, Procedia Environ. Sci., 18, 14-19 (2013)

[3] A. T. S. Azhar, M. A. M. Azmi \& A N A Talib, Stabilization/Solidification Remediation Method for Contaminated Soil: A Review, IOP Conference Series: Materials Science and Engineering, 136 1-6 (2016) 
[4] A. Kamari, I. D. Pulford, and J. S. J. Hargreaves, Binding of heavy metal contaminants onto chitosans--an evaluation for remediation of metal contaminated soil and water, J. Environ. Manage., 92 10, 2675-82, (2011)

[5] C. E. Halim, J. a Scott, R. Amal, S. a Short, D. Beydoun, G. Low, and J. Cattle, Evaluating the applicability of regulatory leaching tests for assessing the hazards of $\mathrm{Pb}$ contaminated soils, J. Hazard Mater., 120 1-3, 101-11 (2005)

[6] J. Aslam, S. A. Khan, and S. H. Khan, Heavy metals contamination in roadside soil near different traffic signals in Dubai, United Arab Emirates, J. Saudi Chem. Soc., 17 3, 315-319 (2013)

[7] A. T. S. Azhar, N. S. Nordin, A. Marto, A. Madun, M.H.Z. Abidin, I. Jefferson, M. A. M. Azmi, "The monitoring and cementation behavior of electrokinetic stabilisation technique on Batu Pahat marine clay, Inter. J. GEOMATE 11 (4), 2581-2588 (2016)

[8] M. W. A. Raouf and H. G. Nowier, Assessment of Fossil Fuel Fly Ash Formulations in the Immobilization of Hazardous Wastes, J. Environ. Eng., 499-507, (2004).

[9] M. T. Montanes, R. Sanchez-Tovar, and M. S. Roux, The effectiveness of the stabilization/solidification process on the leachability and toxicity of the tannery sludge chromium, J. Environ. Manage., 143, 71-9, (2014)

[10]R. Malviya and R. Chaudhary, Factors affecting hazardous waste solidification/stabilization: a review, J. Hazard. Mater.J. Hazard. Mater., 137 1, $267-$ $76(2006)$

[11] A T S Azhar, A. Marto, M. A. M. Azmi, A. Madun \& M. H. Z. Abidin, Utilization of sugarcane Bagasse ash for stabilization/solidification of lead-contaminated soils, Jurnal Teknologi 77:11, 119-125 (2015)

[12] A. T. S. Azhar, M. A. M Azmi , S. Shahidan, M.H.Z. Abidin, A. Madun, Relationship of physical parameters in Pb-contaminated by stabilization/solidification method, MATEC Web of Conferences 47, 1-6 (2016)

[13] A .T. S. Azhar, A T A Nabila, M S Nurshuhaila, M Z N Shaylinda and M A M Azim, Electromigration of Contaminated Soil by Electro- Bioremediation Technique, IOP Conference Series: Materials Science and Engineering, 136 1-6 (2016)

[14] A. T. S. Azhar, A T A Nabila, M S Nurshuhaila, E Zaidi, M. A. M Azmi and S M S Farhana, Assessment and Comparison of Electrokinetic and Electrokineticbioremediation Techniques for Mercury Contaminated Soil, IOP Conference Series: Materials Science and Engineering, 160 1-9 (2016)

[15] A T S Azhar, A T A Nabila, M S Nurshuhaila, E Zaidi, M A M Azim and A M F Zahin, Novel Technique to improve the $\mathrm{pH}$ of Acidic Barren Soil using Electrokinetic-bioremediation with the application of Vetiver Grass, IOP Conference Series: Materials Science and Engineering, 160 1-9 (2016)

[16] A T S Azhar, M A M Azim, M Aziman and A T A Nabila Leachability of Arsenic (As) Contaminated Landfill Soil Stabilised by Cement and Bagasse Ash. IOP Conference Series: Materials Science and Engineering, 160 1-9 (2016)

[17] K. Nemati, N. K. Abu Bakar, M. R. Abas, and E. Sobhanzadeh, Speciation of heavy metals by modified BCR sequential extraction procedure in different depths of sediments from Sungai Buloh, Selangor, Malaysia, J. Hazard. Mater., 192 1, 402-10 (2011)

[18] A. Antemir, C. D. Hills, P. J. Carey, K. H. Gardner, E. R. Bates, and A. K. Crumbie, Long-term performance of aged waste forms treated by stabilization/solidification, J. Hazard. Mater., 181, 1-3, 65-73, ( 2010)

[19] F. Wang, H. Wang, F. Jin, and A. Al-Tabbaa, The performance of blended conventional and novel binders in the in-situ stabilisation/solidification of a contaminated site soil, J. Hazard. Mater., 285C, 46-52 (2014) 